\title{
Quality Analysis of E-government Services Using SERVQUAL Method (Case Study of SAMSAT Office in Kolaka Regency)
}

Analisis Kualitas Layanan E-government Menggunakan Metode SERVQUAL (Studi Kasus Kantor SAMSAT Kabupaten Kolaka)

Received: 10 April 2020

Accepted:

9 June 2020

Published:

19 August 2020

\author{
$1 *$ Nurfitria Ningsi, ${ }^{2}$ Noorhasanah $Z,{ }^{3}$ Gusnawati Gusnawati \\ ${ }^{1,2,3}$ Sistem Informasi, Universitas Sembilanbelas November Kolaka \\ ${ }^{1,2,3}$ Sulawesi Tenggara, Indonesia \\ E-mail: ${ }^{1}$ nurfitrianingsi35@gmail.com, ${ }^{2}$ Noorhasanahzain@ \\ gmail.com, ${ }^{3}$ gusnawati@gmail.com
}

\begin{abstract}
This study discusses the measurement of the quality of motor vehicle tax of information system services at the SAMSAT Kolaka office using the servqual method by emphasizing the five dimensions of servqual namely Tangibles, Reliability, Responsiveness, Assurance and empathy. This study aims to understand the level of user satisfaction by comparing expectations and expectations and updating the standards provided by SAMSAT Kolaka through the application of the SIZ application. Data collection activities were carried out by distributing 100 questionnaires to all SIZ service users. The results of this study indicate that the use of SIZ is not by customer needs; this can be demonstrated by the high value of the gap between expectations and perceptions. The Assurance dimension obtaining the most top difference is the Tangibles dimension indicating that the limitations of the IT facilities used are still limited. It is evidenced by the continued complaints of customers regarding queue buildup due to a system that suddenly goes down while the service is in progress. It is necessary to improve IT infrastructure that can improve customer satisfaction in the future.
\end{abstract}

Keyword-Service Quality, E-government, Servqual, SIZ, Vehicle

\begin{abstract}
Abstrak-Penelitian ini membahas tentang pengukuran kualitas layanan sistem informasi pajak kendaraan bermotor pada kantor SAMSAT kolaka menggunakan metode servqual dengan menekankan pada lima dimensi servqual yakni Tangibles, Reliability, Responsiveness, Assurance dan empathy. penelitian ini bertujuan untuk mengetahui tingkat kepuasan pengguna dengan mengidentifikasi kesenjangan antara persepsi dan harapan dan mencoba memeriksa standar layanan diberikan oleh pihak SAMSAT kolaka melalui penerapan aplikasi SIZ. Aktivitas pengumpulan data dilakukan dengan menyebar koesioner sebanyak 100 kepada seluruh pengguna layanan SIZ. Hasil penelitian ini menunjukan bahwa penggunaan SIZ belum sesuai dengan kebutuhan pelanggan hal ini dapat ditunjukan dengan tingginya nilai gap antara harapan dan persepsi. Dimensi Assurance memperoleh gap tertinggi adalah dimensi Tangibles yang mengindikasikan bahwa keterbatasan fasilitas TI yang digunakan masih terbatas, hal ini dibuktikan dengan masih terdapatnya keluhan pelanggan terkait penumpukan antrian akibat sistem yang tiba-tiba down saat pelayanan sedang berlangsung. Perlu adanya pembenahan infrastruktur TI yang dapat meningkatkan kepuasan pelanggan dimasa mendatang
\end{abstract}

Kata Kunci-Kualitas Layanan, E-government, Servqual, SIZ, Pajak Kendaraan Bermotor 


\section{INTRODUCTION}

Tax is a compulsory levy paid by the people to the State and will be used for the benefit of the government and the general public. People who pay taxes will not feel the benefits of taxes directly because the tax is used for public purposes, not for personal gain [1] — tax as a potential source of income for the government. In Law No.28 of 2007 explaining the general provisions and procedures for taxation, tax is also defined as the contribution of taxpayers to the Stateowned by individuals or entities that are formed based on the Act, with no direct reciprocity and used for the State for the greatest prosperity of the people.

Based on the measurement results, the level of quality of e-commerce services is at a level that has not been satisfied with the value of -1.084 [2]. Besides, the results of the regression test conducted both simultaneously and partially Tangibles, Reliability, Responsiveness, Assurance, and empathy variables contributed 65.9\% to the variable Information System User Satisfaction. It means that it was still not satisfactory enough [3] In line with this, the Reliability Variable still needs improvement so that the services provided are in line with the expectations of the online application users [4]. The direct effect of customer satisfaction variables on customer loyalty variables with coefficient values $(\beta)$ amounted to 0.386 and t-test was 4.785 [5] the importance of considering the appropriateness of customer expectations with the services obtained today, which is inversely proportional to the satisfaction they get [2].

In line with this, there are several other research comparisons from[6] which found that applications owned by PT ABC and XYZ Pte. Ltd. have not provided service quality that is in line with customer expectations because all dimensions of measurement indicate that expectations are higher than customer perceptions. The Assurance dimension in the two applications studied has a gap that is in the top two most senior in the results of data analysis. It indicates that customers expect high security from both applications but cannot be fulfilled by the application provider company. Furthermore[7] found that the level of student satisfaction with the ServQual dimension and gap analysis produced a negative gap which means that the reality received by consumers (students) was not in line with expectations, the company (campus) still had room to improve performance. The most service the gap is in the empathy dimension. It shows that the empathy dimension is the dimension that has the most direct effect on student satisfaction in terms of improving appearance, instructions and full features, followed by the Responsiveness dimension that demands online chat features for 24 hours.

Also supported by findings [8] where the dimensions of empathy (empathy) Tokopedia.com service is still low (Gap = -3.66), where User Quality has the smallest Gap of 0.10 namely Reliability, Responsiveness has the second-lowest Gap of 0.07, Tangible (physical/real) has the 
INTENSIF, Vol.4 No.2 August 2020

ISSN: 2580-409X (Print) / 2549-6824 (Online)

DOI: https://doi.org/10.29407/intensif.v4i2.13707

lowest Gap of -0.04, while Assurance is the fourth lowest with Gap of -0.04. The results of the GAP analysis state that the Tokopedia.com website does not meet the needs of visitors and visitors are not yet satisfied with the quality. And to find out what factors should be prioritized on online registration with the JKN mobile application to meet the expectations of the community[9], significantly at $\mathrm{p}<0.01$, at the value of 5.22 is obtained for empathy dimensions $t$ value of 5.28; for the accountability dimension; for the Tangibles dimension, at the cost of 4.62 is obtained. It indicates the suitability of the quality of service provided by the professor with the expectations of students [10]. The satisfaction level is with a gap of 0.332 ; computer experience with a difference of 0.292 ; essential experience in OA with a gap of 0.3083 with the highest comparison gap which shows the evaluation of learning by applying the dimensions of servqual is not enough to meet student expectations [11]. The average score of the highest servqual dimension gap is the dimensions of Responsiveness, Assurance and Tangibles, which shows that there are still mismatches of service expectations provided with the perceptions of students [12]. The path coefficient model shows that the reliability dimension is the dimension with the lowest priority with a $t$ value of 0.114 , this occurs because distance lectures reduce the instructor's role to be always reliable, primarily related to corrections that are objective [13].

The most prominent gap is the Responsiveness dimension with a weight gap of -0.65 due to the low readiness of the organization to help and provide services quickly to its customers [14], The Assurance dimension with the highest gap of -1.86 which shows that the community's expectation for services provided is not following this matter related to the concern of the staff's authority to behave politely, confidently to the poor people who use their functions [15]. In line with this finding[16] also supports that the low attention on aspects of service quality, especially the dimensions of Assurance with a mean value of 0.152, Tangibles with a mean of 0.140 and empathy with a mean of 0.134 , this proves the low attention of airlines to the perception of users, especially on the quality of baggage handling. Furthermore, the empathy aspect is also a critical spotlight considering this dimension also gets the highest gap among other sizes specifically not being a top priority for the company in providing mobile banking services for its customers[17]

Some problems that cannot be avoided such as the mismatch of reporting the amount of tax paid with the taxpayer's family income is still an essential factor affecting user satisfaction with the tax services provided[18]. Payment methods and hospitality services are some elements that can be developed [19] This is related to the sensitivity of the user to its customers[20]

With the existence of several research references, this study tries to investigate the five dimensions of servqual (Responsiveness, Assurance, Tangibility, Empathy and Reliability) by identifying gaps between perceptions and expectations and trying to check service standards provided by SAMSAT Kolaka through the use of the SIZ application. So that these findings later 
will help SAMSAT to focus on the dimensions of service quality so that it can produce a followup plan for improving the overall service quality.

\section{RESEARCH METHOD}

SERVQUAL method is a method of measuring the quality of service the most used [4] to determine the extent of the quality of information system services implemented to user satisfaction precisely [20] in [21] emphasizes the comparison between the expectations (expectations) and perceptions of users of the services they receive. This gap is evidence of the inability of the organization to meet the expectations of its customers. [22] in [23] focuses servqual into five significant differences:

A. Gaps created due to the inability of the organization/company to translate the expectations of consumers for the services provided.

B. Error in translating the company's management to the expectations of consumers so that the services provided are not optimal/specific.

C. The company organization sets the company's inability to meet service quality standards.

D. The company's inability to meet the needs of consumers who have previously communicated.

E. The mismatch between service expectations expected by the customer and the actual service provided by the company.

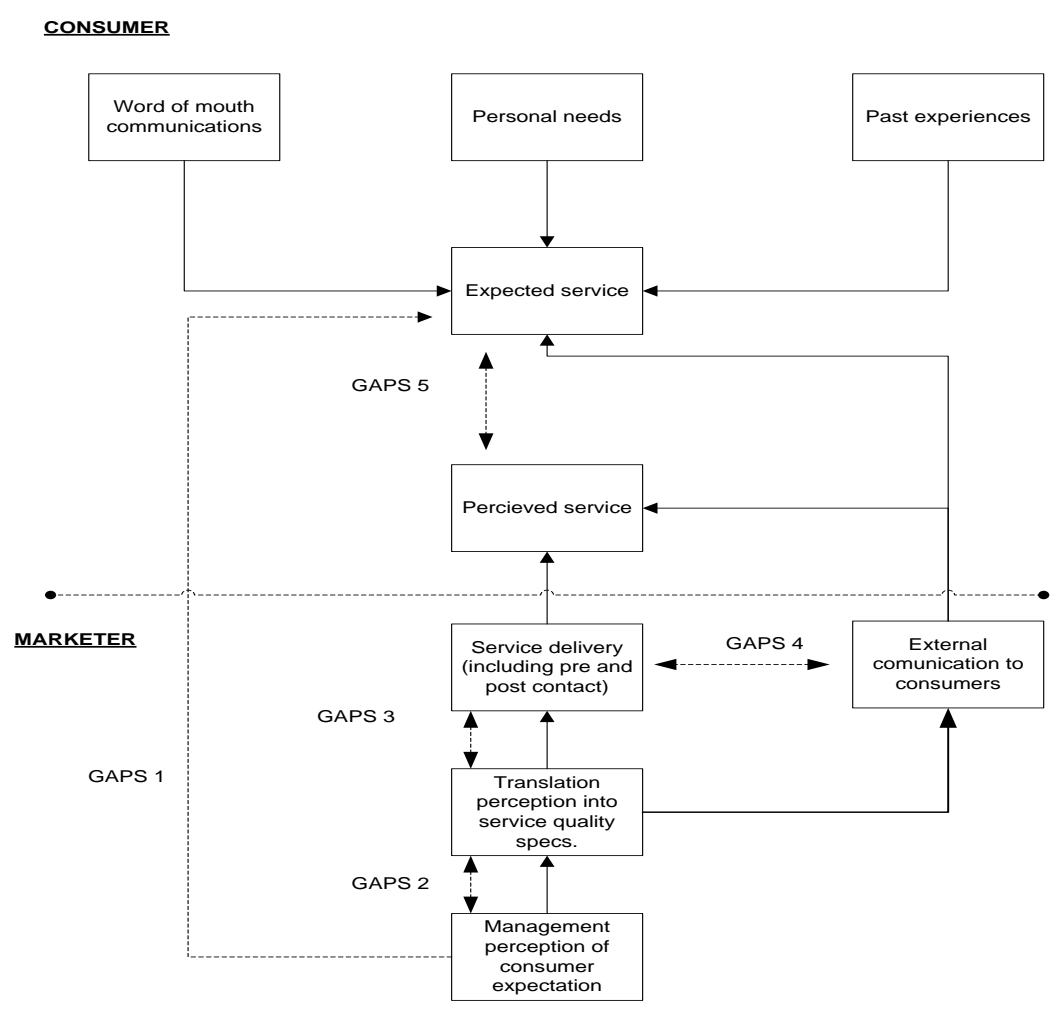

Figure 1. CONCEPTUAL MODEL OF SERVQUAL

Resource; Parasuraman 1985 in astuti 2007 
INTENSIF, Vol.4 No.2 August 2020

ISSN: 2580-409X (Print) / 2549-6824 (Online)

DOI: https://doi.org/10.29407/intensif.v4i2.13707

Measurements are made by Establishing variables and dimensions to be measured later distributing questionnaires; processing the results of the survey; conclude [4] In this study SERVQUAL dimensions consist of: Tangibles (X1), Reliability (X2), Responsiveness (X3), Assurance (X4), empathy (X5). The dependent variable (Y) = User Satisfaction of Samsat Online Information system (SIZ) services. The use of a scale with ordinal data size then the score of respondents' answers will be summed and averaged into an average rating, this score is then interpreted as a valuation position on a Likert scale. Likert scale questionnaire (1-5) to determine the level of customer satisfaction with Samsat services. This study refers to the Likert range used by [7] where consumer satisfaction determines the gap between consumer expectations and the level they are received. The following is a Likert scale table used in this study:

Table 1. LIKERT SCALE

\begin{tabular}{lll}
\hline \hline No & Expectation & Perception \\
\hline 1 & Very unneeded: 1 & Very unsatisfactory: 1 \\
\hline 2 & Not needed: 2 & Not satisfactory: 2 \\
\hline 3 & Neutral $: 3$ & Neutral $: 3$ \\
\hline 4 & Needed: 4 & Satisfying: 4 \\
\hline 5 & Very needed:5 & Very satisfy:5 \\
\hline
\end{tabular}

The analysis results of the processing of the questionnaire made recommendations that can be expressed in numerical values that reflect the level of importance of the variable. Determination of the cost of these results is based on the gap between expected satisfaction and satisfaction received at this time and to identify the effect of the independent variable on the dependent variable used multiple linear regression equations. Dependent variable (dependent variable) and as an independent variable (independent variable). The causal design aims to see the effect of independent variables on the dependent variable. Independent variables consist of Tangibles (X1), Reliability (X2), Responsiveness (X3), Assurance (X4), and Empathy (X5). And the dependent variable of this research proposal is consumer satisfaction (Y). The stages of this study can be seen in the following figure:

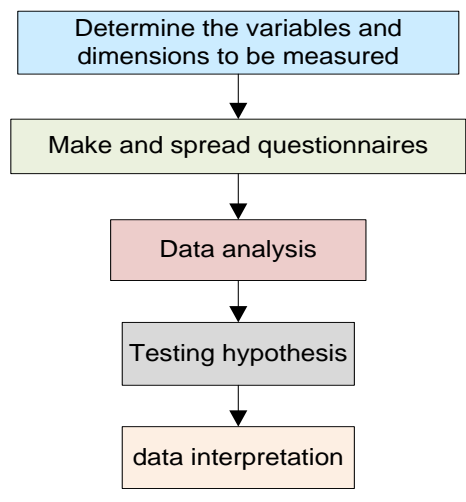

Figure 1. RESEARCH PHASE

146 INTENSIF: Jurnal Ilmiah Penelitian dan Penerapan Teknologi Sistem Informasi 
1. Determine the variables and dimensions to be measured

This research phase begins with the literature study activity then determines what variables and sizes are used in this study refer to [4] a description of each variable, and SERVQUAL dimensions are presented in table 2:

Table 2. DESCRIPTION OF EACH VARIABLE

\begin{tabular}{|c|c|c|c|}
\hline Variable & & Dimension & Indicator \\
\hline \multirow{8}{*}{$\begin{array}{l}\text { Information } \\
\text { Quality }\end{array}$} & \multirow[t]{2}{*}{ Service } & \multirow[t]{2}{*}{ Tangibles } & Facilities \\
\hline & & & Equipment \\
\hline & & Reliability & Accurate \\
\hline & & & Reliable \\
\hline & & Responsiveness & $\begin{array}{l}\text { Staff speed in handling } \\
\text { transactions }\end{array}$ \\
\hline & & Assurance & Competence \\
\hline & & & Courtesy \\
\hline & & Empathy & Understanding of system users \\
\hline User Satisfaction & & Social & $\begin{array}{l}\text { Social interaction between } \\
\text { people }\end{array}$ \\
\hline & & Physical & Environmental conditions \\
\hline
\end{tabular}

2. Questionnaire preparation and questionnaire distribution

Questionnaire preparation and distribution of questionnaires is by distributing a list of written questions that have been determined using a Likert scale to identify the level of customer satisfaction with Samsat services. Consumer satisfaction determines the gap between consumer expectations and the level they are received.

3. Data analysis

Analysis of the results using the SERVQUAL method [3] by analyzing the gap between the level of expectation and perceived quality of the services of vehicle tax information system. Each respondent was given two types of questions. The first question is about the level of expectation of the quality of vehicle-tax information system services. The second question about the level of perception is related to the quality of the services of vehicle tax information system. From the results obtained, it can be seen the level of service quality of the vehicle tax information system by comparing the results of the two questions [8] analysis of the results using:

a. Validity test

Validity test to test whether the research instrument is suitable as a research measurement tool [8].

$$
r_{x y}=\frac{N \sum X Y-\left(\sum X\right)(\Sigma Y)}{\sqrt{\left.\left\{N \sum X^{2}-\sum X\right)^{2}\right\}\left\{N \sum Y^{2}-\left(\sum Y\right)^{2}\right\}}}
$$


INTENSIF, Vol.4 No.2 August 2020

ISSN: 2580-409X (Print) / 2549-6824 (Online)

DOI: https://doi.org/10.29407/intensif.v4i2.13707

b. Reliability Test

Reliability testing uses a split-half technique which is analyzed by the Sperman Brown formula [8].

$$
r_{1}=\frac{2 \cdot r_{b}}{1+r_{b}}
$$

4. Hypothesis testing

Next, test the hypothesis using a regression assumption that provides representative results. The assumption test used in this study uses SPSS (Statistical Product and Service Solutions) software [3] The following conceptual framework proposed refers to [24] in this study:

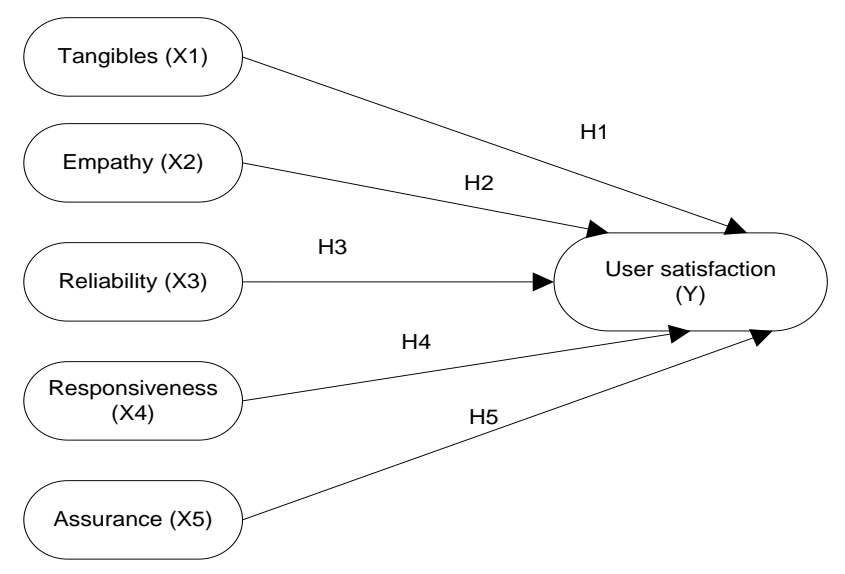

Figure 3. CONCEPTUAL MODEL

Information:

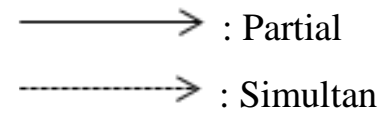

Proposed hypothesis

H1: Tangible, empathy, Reliability, Responsiveness, Assurance are thought to have a significant effect on customer satisfaction at Samsat Kolaka's office.

$\mathrm{H} 2$ : Tangible is suspected of having a significant effect on customer satisfaction at Samsat Kolaka's office.

H3: Empathy is suspected of having a significant effect on customer satisfaction at Samsat Kolaka's office.

H4: Reliability is believed to affect customer satisfaction at the Samsat Kolaka office.

H5: Responsiveness is thought to have a significant effect on customer satisfaction at Samsat Kolaka's office. 
H6: Assurance is thought to have a significant effect on customer satisfaction at the Samsat Kolaka office.

5. Data Interpretation Process

Interpret data by translating data into languages that are easily understood by others.

\section{RESULT AND DISCUSSION}

Gap analysis between the level of expectation and perceived quality of the services of vehicle tax information system uses the paired $\mathrm{f}$ test where each respondent is given two types of questions. The first question is about the level of expectation of the quality of the services of vehicle tax information system. The second question about the level of perception is related to the quality of the services of vehicle tax information system.

\section{A. Validity test}

From the validity, the test shows the value of $r$ table in the table of values of productmoment $\mathrm{r}$ with the provisions of table $=\mathrm{N}=50$ and a significant level of $5 \%$ so the amount of $\mathrm{r}$ table $=0.27$ thus the items on the variable $\mathrm{X}$ can be stated that everything is valid by looking at the value $r$ count of all things is higher than the value of $r$ table. The results of testing the validity of the variable $y$ are obtained $r$ value $>r$ table value. The calculated $r$-value is derived from the relationship between the respondent's answer with the total score of the respondent's answer by using the correl command on Excel while for the $r$ table's value is obtained from the product-moment value. Thus it can be concluded that the $\mathrm{Y}$ variables whose problem items are seven items are all valid because the amount of $r$ counts for each question item are p1 (0.540), p2 (0.541), p3 (0.435), p4 (0.679), p5 (0.62), p6 (0.627), p7 (0.54) is higher than the value of $r$ of the table (0.279).

B. Reliability Test

After conducting the validity test, the next step is to calculate the value of the correlation coefficient and in this study obtained a figure of $=0.663$. These correlation coefficients are then included in the Spearman-Brown formula as below:

$$
\begin{array}{r}
\mathrm{r}_{1}=\frac{2 \cdot r_{b}}{1+r_{b}} \\
\mathrm{r}_{1}=\frac{2 * 0,663}{1+0,663} \\
\mathrm{r}_{1}=0,797
\end{array}
$$

Using the Spearman-Brown formula, the reliability value of all Service Quality variable variables $(\mathrm{X})$ is 0.797 . It can be said to be reliable because it has a Crombach Alpha coefficient above 0.60. This statement is by [24] that a reliable instrument if it has a 
INTENSIF, Vol.4 No.2 August 2020

ISSN: 2580-409X (Print) / 2549-6824 (Online)

DOI: https://doi.org/10.29407/intensif.v4i2.13707

Crombach Alpha score above 0.60. Based on calculations that have been done to the variable

User Satisfaction (Y) using the Spearman-Brown formula obtained the reliability value of all instruments of 0.603 and can be said to be stable because it has a Crombach Alpha coefficient above 0.60 .

C. SERVQUAL Analysis

Referring to the calculation [21] obtained a Gap value which shows the comparison of the level of user expectation on SIZ services with the user's perception of the services provided, this gap is presented in table 3 below:

Table 3. SERVQUAL ANALYSIS

\begin{tabular}{|c|c|c|c|c|}
\hline Dimension & No & Perception & expectation & Gap (P-H) \\
\hline \multirow{4}{*}{ Tangibles } & 1 & 4.24 & 4.7 & -0.46 \\
\hline & 2 & 4.24 & 4.68 & -0.44 \\
\hline & 3 & 4.68 & 4.36 & -0.34 \\
\hline & 4 & 4.34 & 4.76 & -0.42 \\
\hline Average & -0.4 & & & \\
\hline \multirow{2}{*}{ Reliability } & 5 & 4.56 & 4.76 & -0.2 \\
\hline & 6 & 4.58 & 4.76 & -0.18 \\
\hline Average & -0.1 & & & \\
\hline \multirow{3}{*}{ Responsiveness } & 7 & 4.36 & 4.74 & -0.38 \\
\hline & 8 & 4.5 & 4.8 & -0.3 \\
\hline & 9 & 4.6 & 4.78 & -0.18 \\
\hline Average & -0.2 & & & \\
\hline \multirow{3}{*}{ Assurance } & 10 & 4.34 & 4.82 & -0.48 \\
\hline & 11 & 4.68 & 4.84 & -0.16 \\
\hline & 12 & 4.52 & 4.68 & -0.16 \\
\hline Average & -0.2 & & & \\
\hline Empathy & 13 & 4.6 & 4.94 & -0.34 \\
\hline Average & -0.1 & & & \\
\hline \multirow[t]{7}{*}{ Variable Y } & 1 & 4.24 & 4.76 & -0.52 \\
\hline & 2 & 4.24 & 4.7 & -0.46 \\
\hline & 3 & 4.36 & 4.74 & -0.38 \\
\hline & 4 & 4.34 & 4.7 & -0.36 \\
\hline & 5 & 4.56 & 4.8 & -0.24 \\
\hline & 6 & 4.58 & 4.78 & -0.2 \\
\hline & 7 & 4.36 & 4.76 & -0.4 \\
\hline Average & \multicolumn{4}{|c|}{-0.36571} \\
\hline
\end{tabular}

The gap between expectations and perceptions of the quality of the services of vehicle tax information system for each of the Servqual dimensions and the $\mathrm{Y}$ variable of customer satisfaction. Following are the results of the gap analysis for each aspect.

Questions 1 to 4 refer to the tangibles variable with an average gap obtained of -0.415 . The level of expectation of users of tangibles variable on the services of vehicle tax information system can be said to be high because the average respondent assesses "needed" and "very 
necessary". And at the level of perception, the average respondent also answered "satisfactory" and "very satisfying", but there were some respondents who were not satisfied with the services provided to produce a negative value on the gap calculation. It means that there is indeed a difference between perceptions and expectations regarding the quality of the functions of the vehicle tax information system at the Samsat Office.

Questions 5 to 6 refer to the Reliability variable, with an average gap obtained of -0.19 . The level of expectations of users of the Reliability variable in the services of vehicle tax information system can be said to be high because the average respondent assesses "needed" and "very necessary". And at the level of perception, the average respondent also answered "satisfactory" and "very satisfying", but there were some respondents who were not satisfied with the services provided to produce a negative value on the gap calculation. It means that there is indeed a difference between perceptions and expectations regarding the quality of the functions of the vehicle tax information system at the Samsat Office.

Questions 7 to 9 refer to the Responsiveness variable with an average gap obtained of 0.28667. The level of expectations of users of the variable Responsiveness in the services of vehicle tax information system can be said to be high because the average respondent assesses "needed" and "very necessary". And at the level of perception, the average respondent also answered "satisfactory" and "very satisfying", but there were some respondents who were not satisfied with the services provided to produce a negative value on the gap calculation. It means that there is indeed a difference between perceptions and expectations regarding the quality of the functions of the vehicle tax information system at the Samsat Office.

Questions 10 to 12 refer to the Assurance variable with an average gap obtained of 0.26667. The level of expectation of users of the Assurance variable in the services of vehicle tax information system can be said to be high because the average respondent assesses "needed" and "very necessary". And at the level of perception, the average respondent also answered "satisfactory" and "very satisfying", but there were some respondents who were not satisfied with the services provided to produce a negative value on the gap calculation. It means that there is indeed a difference between perceptions and expectations regarding the quality of the functions of the vehicle tax information system at the Samsat Office. Question 13 refers to the empathy variable, with an average gap obtained of -0.34 . The level of expectation of users towards empathy in the services of vehicle tax information system can be said to be high because the average respondent assesses "needed" and "very necessary". And at the level of perception, the average respondent also answered "satisfactory" and "very satisfying", but there were some respondents who were not satisfied with the services provided to produce a negative value on the gap calculation. It means that there is indeed a 
INTENSIF, Vol.4 No.2 August 2020

ISSN: 2580-409X (Print) / 2549-6824 (Online)

DOI: https://doi.org/10.29407/intensif.v4i2.13707

difference between perceptions and expectations regarding the quality of the functions of the vehicle tax information system at the Samsat Office. Questions 1 to 7 refer to the Y variable with an average gap obtained of -0.365 . The level of expectation of users of the $\mathrm{Y}$ variable on consumer satisfaction can be said to be high because the average respondent assesses "needed" and "very necessary". And at the level of perception, the average respondent also answered "satisfactory" and "very satisfying", but there were some respondents who were not satisfied with the services provided to produce a negative value on the gap calculation. It means that there is indeed a difference between perceptions and expectations related to customer satisfaction that receives service from the tax service information system at Samsat Kolaka.

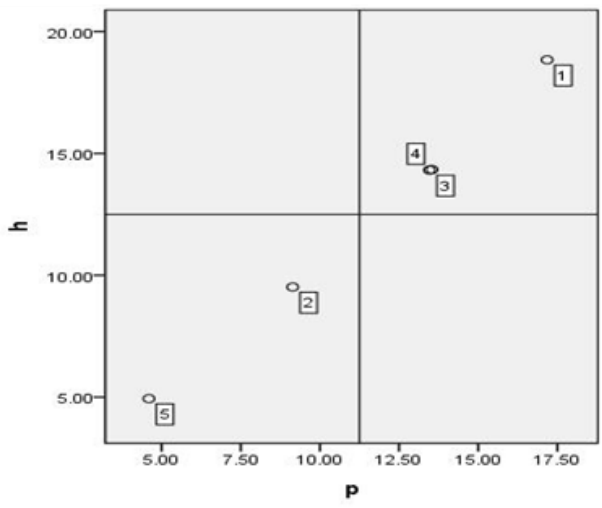

Figure 4. The SERVQual GaP ON THE SERVICE Quality DimENSION (X)

Figure 4 above indicates that Dimensions 1.4, and 3 are classes of variables that need to be corrected and need to be maintained because users who use the system are satisfied with the service of the vehicle tax, namely (SIZ Online). Furthermore, Dimensions 2 and 5 are low priority areas because the variables contained in this variable (Reliability and empathy variables) are considered to be insignificant or not significant by the user. The service is less destructive, but that does not mean this variable does not become a concern because in the future statement or attribute will come to be needed in carrying out the quality of service.

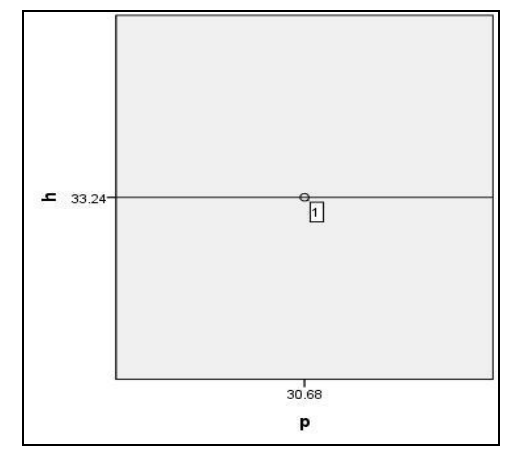

Figure 5. SERVQUAL GAP ON THE USER SATISFACTION DIMENSION (Y) 
INTENSIF, Vol.4 No.2 August 2020

ISSN: 2580-409X (Print) / 2549-6824 (Online)

DOI: https://doi.org/10.29407/intensif.v4i2.13707

Figure 5 indicates that the dimension of user satisfaction is at a gap of -2.56 which shows that the level of user satisfaction is entirely subjective, it can be seen from the facts in the field that the ability of resources that are persuasively able to increase user interest in using this service.

D. Multiple Linear Regression Analysis

Table 4. SUMMARY MODEL

\begin{tabular}{|c|c|c|c|c|}
\hline \multicolumn{5}{|c|}{ Model Summary } \\
\hline Model & $\mathrm{R}$ & R Square & Adjusted R Square & Std. Error of the Estimate \\
\hline 1 & $0,867^{\mathrm{a}}$ & 0,752 & 0,723 & 0,09862 \\
\hline \multicolumn{5}{|c|}{ a. Predictors: (Constant), X5, X2, X1, X3, X4 } \\
\hline \multicolumn{5}{|c|}{ b. Dependent Variable: Y } \\
\hline
\end{tabular}

This table explains the magnitude of the correlation value/relationship (R) that is equal to 0.867 and explained the magnitude of the effect percentage of the independent variable on the dependent variable. It is called the coefficient of determination which is the result of squaring R. From the output obtained a coefficient of detestation (R2) of 0.752 which contains the understanding that the influence of independent variables (X1, X2, X3, X4, X5) on the dependent variable $(\mathrm{Y})$ is $75.2 \%$. In contrast, the rest is influenced by other variables.

Table 5. ANOVA TEST

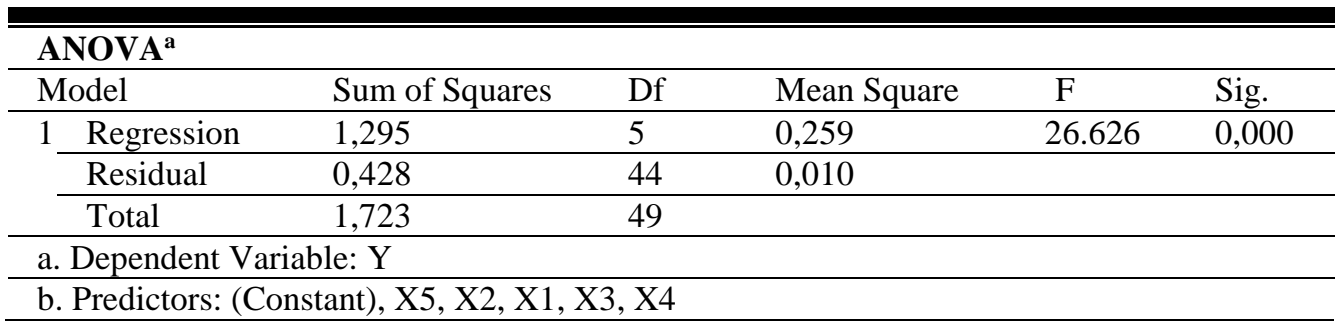

The $F$ test results in the figure show that the Fhitung value of 26,626 with a significant level of 0,000 is smaller than the probability value of 0.05 . And it can be said that all independent variables simultaneously have a significant effect on the dependent variable.

Table 6. COEFFICIENTS TEST

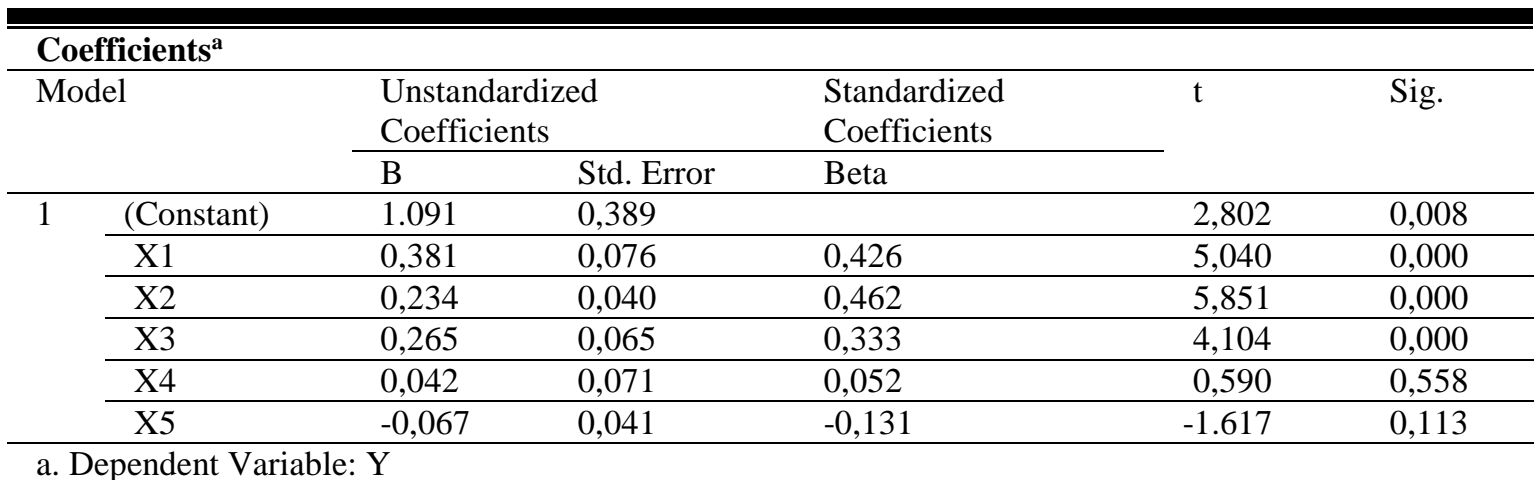


INTENSIF, Vol.4 No.2 August 2020

ISSN: 2580-409X (Print) / 2549-6824 (Online)

DOI: https://doi.org/10.29407/intensif.v4i2.13707

The coefficient test is carried out to measure how much the contribution of the dependent variable is to the independent variable [9] table 3 shows this as the following:

1. The influence of tangibles variable on customer satisfaction

Based on the regression results in Table 16, the t-test results obtained for the tangible variable amounted to 5,040 with a significant level of 000 , which is smaller than 0.05 . based on these criteria, tangibles partially affect consumer satisfaction.

2. Effect of Reliability variable on customer satisfaction

The $t$ value of the Reliability variable is 5,851 with a significance level of 0.00 which is smaller than 0.05 based on these criteria. Reliability influences customer satisfaction.

3. The effect of Responsiveness variables on customer satisfaction

$\mathrm{T}$ value in the Responsiveness variable of 4.104 with a significance level of 0.00 which is smaller 0.05 based on these criteria reliability affects customer satisfaction.

4. The effect of variable Assurance on customer satisfaction

$\mathrm{T}$ value for the Assurance variable is 0.590 with a significant level of 0.558 , which is higher than 0.05 based on these criteria Assurance does not affect customer satisfaction.

5. The influence of empathy variables on customer satisfaction

The $t$ value of the empathy variable is equal to a significant level of 0.113 , which is higher than 0.05 based on these criteria Assurance does not affect customer satisfaction.

E. Hypothesis testing

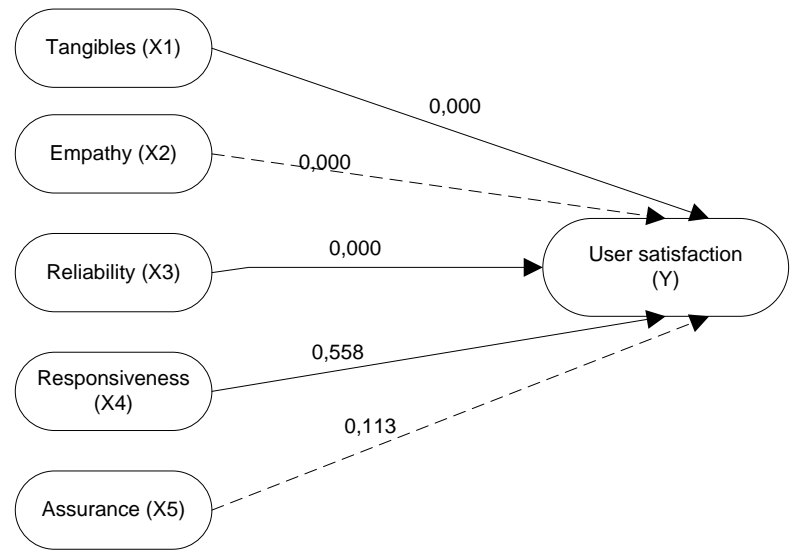

Figure 6. HYPOTHESIS TESTING MODEL

Tangibles (X1), Reliability (X3), and Responsiveness (X4) variables show a significant positive effect on customer satisfaction, Assurance (X5), and empathy (X2) variables with dashed lines indicating. These variables do not directly influence consumer satisfaction meaning that these two dimensions are not the primary determinant of user satisfaction, this 
is in line with findings [25] which show that Responsiveness and Assurance require serious attention considering this dimension is related to the accuracy. Positive feedback, [26] empathy related to recognition to differences in the level of user needs for services provided can improve the quality of the service itself. It is also associated with the ability to respond to customer problems quickly and accurately [8] From multiple linear regression calculations using SPSS; there are several variables that do not affect consumer satisfaction with a significant value of greater than 0.05 including Assurance variables with a considerable amount of 0.590 and empathy variables which have a substantial benefit of 0.113 - thus combining the use of SERVQUAL with decision-support methods such as TOPSIS, AHP and Fuzzy for more objective results [15], [27], [28], with consideration of ease of access to services for products needed by users in the future.

\section{CONCLUSION}

The statistical calculations results show that the service quality of the services of vehicle tax information system at the Samsat Kolaka office is still unsatisfactory, especially dimensions 2 and 5 in which the aspects with the lowest priority considering that this variable is still considered less influencing the quality of service. Also, the gap between perception and expectations of the services of vehicle tax information system for each Servqual dimension obtain an average difference of (-0.415), Reliability (-0.19), Responsiveness (-0.28667), Assurance (-0.26667), empathy (-0.17), and Y variables of (-0.36571). It shows that other factors influence user perceptions when using SIZ services in the form of adequate office infrastructure such as free wifi, sensitivity to customer complaints can be a supporting factor of increasing customer loyalty in the future. Future studies can examine the effect of service quality on the reliability of users of information technology.

\section{REFERENCES}

[1] E. Esse, "Analisis pajak dalam transaksi elektronik," no. November, 2019, [Online]. Available: t: https://www.researchgate.net/publication/337075754\%0AANALISIS.

[2] D. Astuti and F. N. Salisah, "ANALISIS KUALITAS LAYANAN E-COMMERCE TERHADAP KEPUASAN PELANGGAN MENGGUNAKAN METODE ESERVQUAL ( Studi Kasus: Lejel Home Shopping Pekanbaru )," J. Rekayasa dan Manaj. Sist. Inf., vol. 2, no. 1, pp. 44-49, 2016, [Online]. Available: http://ejournal.uinsuska.ac.id/index.php/RMSI/article/view/1784.

[3] Marlindawati, "Analisis Kualitas Layanan Sistem Informasi Menggunakan SERVQUAL,” Semin. Nas. Apl. Teknol. Inf., no. 12, pp. 47-52, 2013.

[4] Fathoni, "ANALISIS KUALITAS LAYANAN SISTEM INFORMASI MENGGUNAKAN METODE SERVQUAL," Konf. Nas. Sist. dan Inform., 2009.

[5] M. G. S. Setiawati, "Analisis Sistem Informasi Aplikasi Online Kartu Kredit 
Menggunakan Metode SERVQUAL,” J. Telekomun. dan Komput., vol. 6, no. 2, p. 103, 2017, doi: 10.22441/incomtech.v6i2.1151.

[6] F. P. Sihotang, "Perbandingan Kualitas Layanan Dua Aplikasi Transportasi Online Menggunakan Metode Servqual,” JATISI (Jurnal Tek. Inform. dan Sist. Informasi), vol. 6, no. 2, pp. 147-162, 2019, doi: 10.35957/jatisi.v6i2.190.

[7] S. Ratnanto and H. Purnomo, "Perceived Dan Expectation Value Dengan Metode SERVQUAL," no. October, pp. 361-367, 2019.

[8] Wahyu Putri haryati, "Analisis Kualitas Tokopedia Menggunakan Metode ServQual," Anal. Kualitas Tokopedia Menggunakan Metod. ServQual, vol. 2, pp. 1-6, 2016.

[9] S. H. S. Andi Saryoko, Hendri, "Pengukuran Kualitas E-Commerce Shopee Terhadap Kepuasan Pengguna," Paradig. J. Komput. dan Inform. Univ. Bina Sarana Inform., vol. 21, no. 2, pp. 143-148, 2019, doi: 10.31294/p.v20i2.

[10] A. Ali, F. Abari, M. Hossein, and M. Esteki, "Assessment of quality of education a nongovernmental university via SERVQUAL model,” vol. 15, pp. 2299-2304, 2011, doi: 10.1016/j.sbspro.2011.04.097.

[11] J. P. Cardona, C. Velazquez, G. Dominguez, J. Munoz, and A. Munoz, "Learning objects evaluation, application of a oriented service model (ServQual)," Proc. - 13th Lat. Am. Conf. Learn. Technol. LACLO, 2018, pp. 1-4, 2018, doi: 10.1109/LACLO.2018.00009.

[12] K. S. Datta and J. Vardhan, "A SERVQUAL-based framework for assessing quality of international branch campuses in UAE: A management students' perspective," SAGE Open, vol. 7, no. 1, 2017, doi: 10.1177/2158244016676294.

[13] G. J. Udo, K. K. Bagchi, and P. J. Kirs, "Using SERVQUAL to assess the quality of elearning experience," Comput. Human Behav., vol. 27, no. 3, pp. 1272-1283, 2011, doi: 10.1016/j.chb.2011.01.009.

[14] E. Akhlaghi, S. Amini, and H. Akhlaghi, "Evaluating Educational Service Quality in Technical and Vocational Colleges using SERVQUAL Model," Procedia - Soc. Behav. Sci., vol. 46, pp. 5285-5289, 2012, doi: 10.1016/j.sbspro.2012.06.424.

[15] M. S. Alam and M. Mondal, "Assessment of sanitation service quality in urban slums of Khulna city based on SERVQUAL and AHP model: A case study of railway slum, Khulna, Bangladesh,” J. Urban Manag., vol. 8, no. 1, pp. 20-27, 2019, doi: 10.1016/j.jum.2018.08.002.

[16] J. Rezaei, O. Kothadiya, L. Tavasszy, and M. Kroesen, "Quality assessment of airline baggage handling systems using SERVQUAL and BWM," Tour. Manag., vol. 66, pp. 85-93, 2018, doi: 10.1016/j.tourman.2017.11.009.

[17] M. Al-Zadjali, H. Al-Jabri, and T. Al-Balushi, "Assessing customer satisfaction of mbanking in Oman using SERVQUAL model,” Proc. IEEE Int. Conf. Softw. Eng. Serv. Sci. ICSESS, vol. 2015-November, pp. 175-178, 2015, doi: 10.1109/ICSESS.2015.7339031.

[18] L. Ibarra, E. Casas, and A. Partida, "Servqual Method Applied to Agencia Fiscal Del Estado De Sonora: An Analysis about Service Quality," Procedia - Soc. Behav. Sci., vol. 148, pp. 87-93, 2014, doi: 10.1016/j.sbspro.2014.07.021.

[19] R. Indrayani, "Analisis Kepuasan Pelanggan Dengan Menggunakan Model Servqual (Studi Kasus Di Ahass Tunas Hartana Motor)," Semin. Nas. Teknol. Informasi, Bisnis, dan Desain 2016, no. August, 2016, [Online]. Available: https://www.researchgate.net/publication/327305793_ANALISIS_KEPUASAN_PELA NGGAN_DENGAN_MENGGUNAKAN_MODEL_SERVQUAL_STUDI_KASUS_DI _AHASS_TUNAS_HARTANA_MOTOR.

[20] A. T. Sambodo, ) Harya, and B. Dirgantara, "Analisis Kepuasan Konsumen Dengan Servqual Studi Kasus: Media Sosial Bhinneka.Com,” Semin. Nas. Sist. Inf. Indones., no. September, 2014.

[21] V. A. Zeithaml and L. L. Berry, "SERVQUAL : A multiple- Item Scale for measuring consumer perceptions of service quality," no. January, 1988.

[22] A. Parasuraman, V. A. Zeithaml, and L. L. Berry, "A Conceptual Model of Service 
Quality and Its Implications for Future Research,” J. Mark., vol. 49, no. 4, p. 41, 1985, doi: $10.2307 / 1251430$.

[23] H. J. Astuti, "ANALISIS KEPUASAN KONSUMEN (SERVQUAL Model dan," J. Media Ekon., vol. 7, no. 1, pp. 1-20, 2007, [Online]. Available: http://id.portalgaruda.org/?ref=browse \&mod=viewarticle \&article $=9606$.

[24] S. Marlin, P. Studi, T. Industri, U. Bung, and K. Jakarta, "ANALISIS PENGARUH KUALITAS LAYANAN DAN KUALITAS PRODUK TERHADAP KEPUASAN DAN LOYALITAS PELANGGAN LAYANAN DATA 4G: Studi Kasus PT . Internux," vol. 9, no. 2, pp. 173-188, 2017.

[25] L. Ocampo et al., "Public service quality evaluation with SERVQUAL and AHPTOPSIS: A case of Philippine government agencies," Socioecon. Plann. Sci., vol. 68, 2019, doi: 10.1016/j.seps.2017.12.002.

[26] A. Pradela, "Quality of Graduates' Preparation for Labour Market - A ServQual Analysis," Procedia - Soc. Behav. Sci., vol. 174, pp. 1671-1677, 2015, doi: 10.1016/j.sbspro.2015.01.820.

[27] R. Liu et al., "Applying the fuzzy SERVQUAL method to measure the service quality in certification \& inspection industry," Appl. Soft Comput. J., vol. 26, pp. 508-512, 2015, doi: 10.1016/j.asoc.2014.10.014.

[28] M. E. Souri, F. Sajjadian, R. Sheikh, and S. S. Sana, "Grey SERVQUAL method to measure consumers' attitudes towards green products - A case study of Iranian consumers of LED bulbs," J. Clean. Prod., vol. 177, pp. 187-196, 2018, doi: 10.1016/j.jclepro.2017.12.105. 